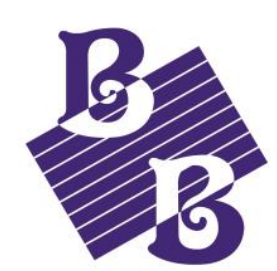

BioBacta

Journal of Bioscience and Applied Research www.jbaar.org

\title{
Morphospecies diversity of soil invertebrates in Cultivated and Uncultivated fields
}

\author{
Abrar Maqtan $^{1}$, Hishamuddin $\operatorname{Omar}^{1}$, Muskhazli Mustafa ${ }^{1}$, Nur Ain M Izzati ${ }^{1}$, Daljit Singh $\operatorname{Karam}^{2}$ \\ ${ }^{1}$ Department of Biology, Faculty of Science, Universiti Putra Malaysia 43400, Serdang, Selangor, Malaysia The Detailed \\ Postal Address of the First Author \\ ${ }^{2}$ Department of Land Management, Faculty of Agriculture, Universiti Putra Malaysia, 43400 UPM Serdang, Selangor, \\ Malaysia. \\ (Email: hishamspirulina@gmail.com)
}

\section{Abstract}

DOI: 10.21608/jbaar.2018.154947

The soil environment is teeming with living organisms full of biological life and is one of the most abundant and diverse ecosystems on earth. However, due to unsustainable agriculture practices, the fertile topsoil is often lost; the soil becomes useless for agriculture. Therefore, we cannot lose sight of the fundamental role of the soil biological entities in maintaining the sustainability of the soil, and the role of organism's biodiversity in the soil to counter against various stress. Therefore, the main objective of this work is detecting diversity and density of soil invertebrates between a cultivated field (Ladang 2) and uncultivated field (CEFS), Results showed that the highest abundance of invertebrates was recorded at CEFS 834 with $3.7 \mathrm{~m} 2$ density and the lowest was in Ladang 2: 225 with $1.2 \mathrm{~m} 2$ density, belonging to 35 different morphospecies from 4 Phylum, 4 subphyla, 6 class, 2 subclass, and 19 orders. A total of 15 morphospecies were collected in the cultivated field Ladang 2, while 25 morphospecies were collected in the uncultivated filed CEFS. Out of 25 morphospecies found in this area, 10 were exclusive to this environment. Annelida, Amphipoda, Isopoda, Collembola, and Hymenoptera were the dominant taxa in CEFS, comprising: 8.15\%, 10.55\%, 17.98\%, $14.14 \%$, and 26.97\% respectively. But Acarina, Coleoptera, and Insect larva 39.68\%, 5.95\%, and 3.97\% respectively were the dominant taxa in Ladang 2. The diversity was highest in the CEFS $(\mathrm{H}=2.29)$ and lowest in the Ladang2 field $(\mathrm{H}=1.74)$. Unfortunately, many aspects of the soil invertebrates have not been documented in Malaysia. For example, why they become dominant in a certain location and what is the impact on that particular ecosystem. This study showed that it is essential to maintain natural habitat because agricultural practices have a major influence on soil invertebrate diversity and hopefully through this study able to suggest sound agriculture management to safeguard the soil ecosystems. Due to the limited information about soil invertebrates in Malaysia and the limited scope of this study, it is premature to make any conclusion and therefore warrant further studies.

Keywords: cultivated land; diversity; morphospecies; uncultivated land; soil Invertebrates.

\section{Introduction}

Although not seen by the naked eye, the soil environment teems with living organisms and is among the most diverse ecosystems on earth. Soil flora and fauna with their vast range of functions actively contribute to the development, structure, and productivity of the soil (McCauley, 2005). The wide range and the sheer number of soil invertebrates play critical roles in subsoil and topsoil operations, which 
are also affected by regional factors such as climatic conditions, soil parent matter, elevation, and ground cover patterns (Grossi \& Brun, 1997; Materna, 2004; Çakıra \& Makinecib, 2018). One of the soil ecosystem processes is the recycling of nutrients by soil invertebrates which are responsible for the decomposition of organic matter (Mason, 1980; Haag et al., 1985; Lavelle et al., 1992). The role of invertebrates in this operation includes the breakdown and redistribution of plant residues (Correia \& Oliveira, 2000), or indirect energizing of microbial activity and the regulation of decaying fungal groups (Moço et al., 2005). Additionally, soil invertebrates also contribute to soil fertility by the decomposition of organic matter. Disruption of the invertebrates community in the soil is the result of changes in the environment (Correia, 2002), very often caused by human activities. Differences in the composition of vegetation, soil management, quality of soil litter, food availability, degree of ecosystem degradation or restoration have significant impacts on the soil invertebrate community (Moço et al., 2005; Silva et al., 2006Baretta et al., 2008; Dias et al., 2007; Azevedo et al., 2008; Ribas et al., 2011; Cunha Neto et al.,2012). Although some soil biota can adapt to harsh environmental conditions, total activity generally decreases when conditions degrade beyond the optimal range (McCauley, 2005). A well-managed site for native vegetation and other fauna using natural processes is also conducive for native invertebrates as they are the lowest common denominator of their societies. Biological indicators are genus or groups of species that reflect the influence of habitat alterations due to their susceptibility to environmental conditions (McGeoch, 1998). Since invertebrates are often specific to certain environmental conditions, are abundant, and are associated with ecosystem processes, and they may serve as useful indicators. Some species respond more to environmental changes than others or have certain characteristics that make them useful to indicate changes in the ecosystem or to monitor environmental conditions (Hutcheson et al. 1999; Greg, and Alison, 2016). However, the major and most diverse community groups of native invertebrates are those found in relatively undisturbed or natural sites (Patrick, 1994). The interactions between soil environmental differences and soil invertebrates are not commonly used in soil quality assessment (Cunha Neto et al., 2012). It is well recognized that excessive human activities such as changes in reforestation and destructive land-use may have significant impacts on biodiversity (Vitousek et al., 1997; Sala et al., 2000; León-Gamboa et al., 2010; Çakıra \& Makinecib, 2018). Therefore, human activities and degradation in environmental conditions resulting from global climate change can potentially influence the native communities of soil invertebrates (Nielsen \& King, 2015). Management practice may affect the diversity of invertebrates in the soil, acting through direct quality (litter quality) and indirect effects (microhabitats, environmental factors such as $\mathrm{pH}$, soil moisture, and soil fertility) (Kinasih et al., 2016). All these lead to disturbances in the ecosystem or ecological imbalance such as the breakdown of forest areas leading to the direct extinction of some species (Loyola et al., 2006). Malaysia is a developing country in the tropics where local soil fauna is often unappreciated and suffers from human influence. In the quest for sustainable living, there is a need for more scientific information that can facilitate political decisions to be made related to soil conservation. Past studies have shown that human activities often lead to soil deterioration and reduction in the abundance of soil fauna. In most cases, the stress-tolerant species prevail and scarce varieties fall in abundance or disappear as the result of intensification in agriculture (Fauziah et al., 1997; Eisenbeis, 2006; Jeffery et al., 2010; Menta, 2012). However, there is a lack of studies about soil diversity of invertebrate communities and aspects of soil biology in Malaysia Thus; this paper offers new data about soil invertebrates communities of two locations in Malaysia that have different soil characteristics. The main objective was to make a comparison of the morphospecies composition, diversity, and density of the soil fauna between a natural or untouched site of management practice (CEFS) and a cultivated site with some farming and human activities (Ladang 2).

\section{Materials and Methods}

\subsection{Study area}

This study was carried out in August 2017 and January 2018, in Malaysia. Two study areas were chosen and compared - one untouched by human activity and soil impacted by human activities. The first is the Ladang 2, which is a research plot in the Universiti Putra Malaysia (UPM) campus, with some farming and other human activity $\left(300^{\prime} 31.22^{\prime \prime} \mathrm{N}\right.$, $\left.101042^{\prime} 12.92^{\prime \prime} \mathrm{E}\right)$. The second plot is known to be a grass area behind the Faculty of Environmental Studies, UPM, with no known human activities $\left(300^{\prime} 22.38^{\prime \prime} \mathrm{N}, 101042^{\prime} 29.57^{\prime \prime} \mathrm{E}\right)$.

\subsection{Procedures}

Two methods were used to collect samples: pitfall traps for invertebrate's surface soil (Maftu'ah et al, 2005), and Berlese funnels to separate micro invertebrates from soil samples (Southwood, 1994). The large invertebrates were then sorted manually in the laboratory. In each sampling plot, a quadrant (of 
$15 \times 15 \mathrm{~m})$ was selected randomly and further divided into 9 subplots $(5 \times 5 \mathrm{~m})$. The distance between traps was 5 meters. The trap was made from a plastic bottle and cut into $10.5 \mathrm{~cm}$ length and $7.5 \mathrm{~cm}$ width and carefully placed in holes at soil level. Each trap contained about $50 \mathrm{ml}$ detergent solution and was left in the field for about 24 hours. Another 9 soil core samples $(5 \mathrm{~cm}$ depth) were taken at random from each plot to collect micro invertebrates, brought to the laboratory, and placed in Berlese funnels (Çakır \& Makineci, 2018). All samples collected were stored in a jar containing $70 \%$ ethanol. From each sample, with the aid of a dissecting microscope, the number of invertebrates was counted. The collected invertebrates were then identified to the possible taxonomic level (using a dissecting microscope), applying the ecological pattern (morphologically-based classification) based on the dichotomous key classification and categorized as an adult or immature (Wade et al., 1989; Thyssen, 2010). Record of abundance in each sample was done by counting the total number for each taxon or morphospecies, in the laboratory of plant physiology, Faculty of Science, UPM.

\subsection{Data analysis}

\subsubsection{Taxonomic groups}

The results of the invertebrate community analyses were recorded for each soil sample, as density (i.e., individual number/m2 soil) and relative abundance (i.e., individual number of each taxon/individual number) (Santorufo et al., 2012).

\subsubsection{Biological indices}

The species diversity was calculated by the Shannon Diversity Index (Shannon, 1949). Data were entered into the spreadsheet that could be set up to automatically calculate the diversity index

Shannon Index $(\mathrm{H})=-\sum_{i=1}^{s} p i \ln p i$

$\mathrm{p}=$ proportion $(\mathrm{n} / \mathrm{N}), \mathrm{n}=$ one particular species found, $\mathrm{N}=$ total number of individuals found.

$\ln =$ natural $\log , \Sigma=$ sum of the calculations. $\mathrm{s}$ $=$ number of species.

Dominance indicators were according to the Simpson index (Simpson, 1949): Simpson Index (D)
$=\frac{1}{\sum_{i=1}^{\S} p^{2}}$

Similarity index: Sorenson's index $(\mathrm{QS})=\frac{2 * C}{A+B}$

$\mathrm{C}=$ number of species the two communities have in common. $\mathrm{A}=$ total number of species found in community $1, \mathrm{~B}=$ total number of species found in community 2 .

\subsubsection{Statistical analysis}

Statistical analysis was performed with IBM SPSS statistics version 23. Data of invertebrates after the normality test were tested using the Kruskal Wallis test and a value of $\mathrm{P} \leq 0.05$ was considered to be the level of statistical significance.

\section{Results}

\subsection{Taxonomic groups}

A total of 1,086 individuals were collected during the sampling period. Among the two study areas, CEFS had the highest abundance of individuals totaling 834 (Table1), followed by Ladang 2 with 252 individuals. Table2 shows morphospecies classification into four Phylum: (Annelida, Nematoda, Arthropoda, and Mollusca), four subphyla (Crustacea, Myriapoda, Chelicerata, and Hexapoda), six classes (Oligochaeta, Gastropoda, Malacostraca, Arachnida, Entognatha, and Insecta), two subclasses (Acari and Collembola) and 19 orders.

\subsection{Density of invertebrate categories:}

Table 3 shows the density between invertebrates from different categories. The highest density was in CEFS with 3.70 individual $/ \mathrm{m}^{2}$. Invertebrate categories with high densities included Hymenoptera, Amphipoda, Collembola, Isopoda, and Annelida comprising $1.00,0.66,0.52,0.39$, and 0.30 individual $/ \mathrm{m}^{2}$ respectively. Overall, invertebrates density in Ladang 2 was 1.12 individual $/ \mathrm{m} 2$ represented by Acarina, Coleoptera, and Insect larva comprising $0.44,0.06$, and 0.044 individual $/ \mathrm{m} 2$. respectively. Kruskal Wallis test indicated that the mean abundance of soil invertebrates at CEFS was highly significant at $(\mathrm{P}=.000)$ than Ladang $2(\mathrm{P}=0.05)$ (Table 4). 
Table 1: Composition and abundance of soil invertebrates collected by traps and funnels from study sites

\begin{tabular}{|c|c|c|c|c|c|c|c|}
\hline \multicolumn{3}{|c|}{ CEFS } & \multicolumn{3}{|c|}{ Ladang 2} & & \multirow{2}{*}{$\begin{array}{l}\text { Grand } \\
\text { Total }\end{array}$} \\
\hline Taxon & Traps & Funnels & Total & Traps & Funnels & Total & \\
\hline Annelida & 63 & 5 & 68 & 4 & NF & 4 & 72 \\
\hline Nematoda & 19 & 5 & 24 & 4 & 4 & 8 & 32 \\
\hline Isopoda & 88 & $* \mathrm{NF}$ & 88 & NF & NF & NF & 88 \\
\hline Amphipoda & 150 & $\mathrm{NF}$ & 150 & $\mathrm{NF}$ & $\mathrm{NF}$ & $\mathrm{NF}$ & 150 \\
\hline Myriapoda & 8 & 1 & 10 & 2 & NF & 2 & 12 \\
\hline Acarina & 14 & 17 & 31 & 47 & 53 & 100 & 131 \\
\hline Araneae & 16 & 1 & 17 & 6 & 4 & 10 & 27 \\
\hline Gastropoda & 11 & $\mathrm{NF}$ & 11 & $\mathrm{NF}$ & $\mathrm{NF}$ & NF & 11 \\
\hline Collembola & 112 & 6 & 118 & 5 & 2 & 7 & 125 \\
\hline Diplura & 2 & $\mathrm{NF}$ & 2 & $\mathrm{NF}$ & $\mathrm{NF}$ & NF & 2 \\
\hline Diptera & 31 & 1 & 32 & 2 & $\mathrm{NF}$ & 2 & 34 \\
\hline Psocoptera & 6 & $\mathrm{NF}$ & 6 & 1 & NF & 1 & 7 \\
\hline Coleoptera & 12 & $\mathrm{Nf}$ & 12 & 15 & $\mathrm{NF}$ & 15 & 27 \\
\hline Hymenoptera & 224 & 1 & 225 & 59 & 21 & 80 & 305 \\
\hline Mecoptera & 7 & $\mathrm{Nf}$ & 7 & 1 & $\mathrm{NF}$ & 1 & 8 \\
\hline Orthoptera & 2 & $\mathrm{Nf}$ & 2 & 4 & $\mathrm{NF}$ & 4 & 6 \\
\hline Hemiptera & 12 & $\mathrm{Nf}$ & 12 & 6 & $\mathrm{NF}$ & 6 & 18 \\
\hline Isoptera & 1 & $\mathrm{Nf}$ & 1 & 2 & $\mathrm{NF}$ & 2 & 3 \\
\hline Ephemeroptera & 1 & $\mathrm{Nf}$ & 1 & $\mathrm{NF}$ & $\mathrm{NF}$ & $\mathrm{Nf}$ & 1 \\
\hline Insect larvae & 4 & 1 & 5 & 8 & NF & 10 & 15 \\
\hline Plecoptera & 3 & $\mathrm{Nf}$ & 3 & $\mathrm{NF}$ & $\mathrm{NF}$ & $\mathrm{Nf}$ & 3 \\
\hline Dermaptera & 2 & $\mathrm{Nf}$ & 2 & $\mathrm{NF}$ & $\mathrm{NF}$ & $\mathrm{Nf}$ & 2 \\
\hline Thysanoptera & 2 & 1 & 3 & NF & $\mathrm{NF}$ & $\mathrm{Nf}$ & 3 \\
\hline Blattodea & 2 & $\mathrm{Nf}$ & 2 & NF & NF & $\mathrm{Nf}$ & 2 \\
\hline Siphonaptera & 1 & 1 & 2 & NF & NF & NF & 2 \\
\hline Total & 793 & 41 & 834 & 166 & 86 & 252 & 10 \\
\hline
\end{tabular}

$* \mathrm{Nf}=$ not found 
Table2: Morphospecies classification and abundance of soil invertebrates in UPM

\begin{tabular}{|c|c|c|c|c|c|}
\hline Phylum & Subphylum & Class & Subclass & Order & number \\
\hline Annelida & & Oligochaeta & & & 72 \\
\hline Nematoda & & & & & 32 \\
\hline Mollusca & & Gastropoda & & & 11 \\
\hline \multirow[t]{21}{*}{ Arthropoda } & Crustacea & Malacostraca & & Isopoda & 88 \\
\hline & & & & Amphipoda & 150 \\
\hline & Myriapoda & & & & 12 \\
\hline & Chelicerata & Arachnida & Acari & Acarina & 131 \\
\hline & & & & Araneae & 27 \\
\hline & Hexapoda & Entognatha & Collembola & & 125 \\
\hline & & & & Diplura & 2 \\
\hline & & Insecta & & Diptera & 34 \\
\hline & & & & Psocoptera & 7 \\
\hline & & & & Coleoptera & 27 \\
\hline & & & & Hymenoptera & 305 \\
\hline & & & & Mecoptera & 8 \\
\hline & & & & Orthoptera & 6 \\
\hline & & & & Hemiptera & 18 \\
\hline & & & & Isoptera & 3 \\
\hline & & & & Ephemeroptera & 1 \\
\hline & & & & Plecoptera & 3 \\
\hline & & & & Dermaptera & 2 \\
\hline & & & & Thysanoptera & 3 \\
\hline & & & & Blattodea & 2 \\
\hline & & & & Siphonaptera & 2 \\
\hline
\end{tabular}

\subsection{Invertebrates diversity}

Table 4 shows that the diversity index for CEFS with $\mathrm{H}=2.3$ was more diverse than Ladang 2 with $\mathrm{H}=1.7$. Both sites have similar 15 morphospecies, therefore the similarity index between the $\mathrm{n}$ two sites was $\mathrm{QS}=0.75$. The prominent taxa were Annelida, Amphipoda, Isopoda, collembola, and Hymenoptera were the dominant taxa in CEFS: $8.15 \%, 10.55 \%, 17.98 \%, 14.14 \%$, and $26.97 \%$ respectively. In Ladang 2, the prominent taxa were Acarina, Coleoptera, and insect larva: $39.68 \%, 5.95 \%$, and $3.97 \%$ respectively (Table 4 ). 
Table 3: The density of invertebrates categories in both sites

\begin{tabular}{|c|c|c|c|c|}
\hline Taxon & CEFS & Density & Ladang 2 & Density \\
\hline Annelida & 68 & 0.30 & 4 & 0.02 \\
\hline Nematoda & 24 & 0.11 & 8 & 0.04 \\
\hline Isopoda & 88 & 0.39 & NF & 0.00 \\
\hline Amphipoda & 150 & 0.67 & NF & 0.00 \\
\hline Myriapoda & 10 & 0.04 & 2 & 0.01 \\
\hline Acarina & 31 & 0.14 & 100 & 0.44 \\
\hline Araneae & 17 & 0.08 & 10 & 0.04 \\
\hline Gastropoda & 11 & 0.05 & $\mathrm{NF}$ & 0.00 \\
\hline Collembola & 118 & 0.52 & 7 & 0.03 \\
\hline Diplura & 2 & 0.01 & $\mathrm{NF}$ & 0.00 \\
\hline Diptera & 32 & 0.14 & 2 & 0.01 \\
\hline Psocoptera & 6 & 0.03 & 1 & 0.00 \\
\hline Coleoptera & 12 & 0.05 & 15 & 0.07 \\
\hline Hymenoptera & 225 & 1.00 & 80 & 0.36 \\
\hline Mecoptera & 7 & 0.03 & 1 & 0.00 \\
\hline Orthoptera & 2 & 0.01 & 4 & 0.02 \\
\hline Hemiptera & 12 & 0.05 & 6 & 0.03 \\
\hline Isoptera & 1 & 0.00 & 2 & 0.01 \\
\hline Ephemeroptera & 1 & 0.00 & $\mathrm{NF}$ & 0.00 \\
\hline Insect larvae & 5 & 0.02 & 10 & 0.04 \\
\hline Plecoptera & 3 & 0.01 & $\mathrm{NF}$ & 0.00 \\
\hline Dermaptera & 2 & 0.01 & $\mathrm{NF}$ & 0.00 \\
\hline Thysanoptera & 3 & 0.01 & $\mathrm{NF}$ & 0.00 \\
\hline Blattodea & 2 & 0.01 & $\mathrm{NF}$ & 0.00 \\
\hline Siphonaptera & 2 & 0.01 & $\mathrm{NF}$ & 0.00 \\
\hline Total & 834 & 3.71 & 252 & 1.12 \\
\hline
\end{tabular}


Table 4: The diversity index for CEFS and Ladang 2

\section{Sites}

Taxon

CEFS

Ladang 2

\begin{tabular}{|c|c|c|c|c|}
\hline & Mean & Percentage & Mean & Percentage \\
\hline Annelida & $7.55 \pm 0.72^{\mathrm{a}}$ & $8.15 \%$ & $0.44 \pm 0.17^{b}$ & $1.59 \%$ \\
\hline Nematoda & $2.66 \pm 0.23^{\mathrm{a}}$ & $2.90 \%$ & $0.88 \pm 0.11^{\mathrm{b}}$ & $3.17 \%$ \\
\hline Isopoda & $9.77 \pm 0.87^{\mathrm{a}}$ & $10.55 \%$ & & \\
\hline Amphipoda & $16.66 \pm 0.80^{\mathrm{a}}$ & $17.98 \%$ & & \\
\hline Myriapoda & $2.50 \pm 1.00^{\mathrm{a}}$ & $1.19 \%$ & $0.50 \pm 0.28^{\mathrm{b}}$ & $0.79 \%$ \\
\hline Acarina & $3.44 \pm 0.33^{\mathrm{b}}$ & $3.71 \%$ & $11.11 \pm 1.0^{\mathrm{a}}$ & $39.68 \%$ \\
\hline Areaneae & $1.88 \pm 0.53^{\mathrm{a}}$ & $2.03 \%$ & $1.11 \pm 0.11^{\mathrm{b}}$ & $3.97 \%$ \\
\hline Gastropoda & $3.66 \pm 1.20^{\mathrm{a}}$ & $1.31 \%$ & & \\
\hline Collembola & $13.11 \pm 1.60^{\mathrm{a}}$ & $14.1 \%$ & $0.77 \pm 0.27^{\mathrm{b}}$ & $2.77 \%$ \\
\hline Diplura & $1.00 \pm 000^{\mathrm{a}}$ & $0.24 \%$ & & \\
\hline Diptera & $4.00 \pm 1.050^{\mathrm{a}}$ & $3.83 \%$ & $0.25 \pm 0.16^{\mathrm{b}}$ & $0.79 \%$ \\
\hline Psocoptera & $3.00 \pm 000$ & $0.71 \%$ & $0.50 \pm 0.50^{\mathrm{a}}$ & $0.39 \%$ \\
\hline Coleoptera & $1.50 \pm 0.32^{\mathrm{b}}$ & $1.43 \%$ & $1.87 \pm 0.22^{\mathrm{a}}$ & $5.95 \%$ \\
\hline Hymenoptera & $20.66 \pm 8.80^{\mathrm{a}}$ & $26.90 \%$ & $8.88 \pm 0.73^{\mathrm{b}}$ & $31.7 \%$ \\
\hline Mecoptera & $2.33 \pm 0.88^{\mathrm{a}}$ & $0.83 \%$ & $0.33 \pm 0.33^{\mathrm{b}}$ & $0.39 \%$ \\
\hline Orthoptera & $0.33 \pm 0.16^{\mathrm{b}}$ & $0.23 \%$ & $0.44 \pm 0.24^{\mathrm{a}}$ & $1.59 \%$ \\
\hline Hemiptera & $1.28 \pm 0.18^{\mathrm{b}}$ & $8.15 \%$ & $0.85 \pm 0.26^{\mathrm{a}}$ & $2.38 \%$ \\
\hline Isoptera & $4.00 \pm 00$ & $2.90 \%$ & $2.00 \pm 0.00$ & $0.79 \%$ \\
\hline Ephemeroptera & $1.00 \pm 000$ & $10.5 \%$ & & $0.43 \%$ \\
\hline Insectlarva & $0.57 \pm 0.29^{b}$ & $0.59 \%$ & $1.42 \pm 0.20^{\mathrm{a}}$ & $3.97 \%$ \\
\hline Plecoptera & $1.33 \pm 0.33$ & $1.19 \%$ & & \\
\hline Dermaptera & $1.00 \pm 000$ & $3.71 \%$ & & \\
\hline Thysanoptera & $1.00 \pm 000$ & $2.03 \%$ & & \\
\hline Blattodea & $1.00 \pm 000$ & $1.31 \%$ & & \\
\hline Siphonaptera & $0.33 \pm 0.500 \mathrm{a}$ & $14.14 \%$ & & \\
\hline Shannon Index & 2.3 & & 1.7 & \\
\hline Simpson index & 6.6 & & 3.7 & \\
\hline Sorenson's index & & 0.75 & & \\
\hline
\end{tabular}

All data are mean $\pm S E(n=140)$ means followed by a different letter are significantly at $P<0.05$ 


\subsection{Function groups}

To simplify the explanation, the soil invertebrates were divided into three size categories (Lavelle et al 1996) (Figure1). The first category, also known as macrofauna with a size of $10 \mathrm{~mm}$ or more, forms $25.30 \%$ of soil invertebrates in CEFS and only $5.40 \%$ in Ladang 2 (Figure 2). The macrofauna (Group1) comprises Annelida-like earthworms, Mollusca, Myriapoda, Hymenoptera like ants and Isoptera or termites, and another Insect like Orthoptera, Coleoptera, and Diptera. Mesofauna (Group 2), the intermediate size between macrofauna and Microfauna (Group 3) comprises $6.70 \%$ in CEFS and $4.22 \%$ in Ladang 2. Members of Mesofauna were Small Annelida, Acarina, Collembola, small Myriapoda and diplura. The final group was Microfauna which consisted of only $0.91 \%$ in CEFS and $0.31 \%$ in Ladang 2 . The three groups can be categorized based on how they interact with their habitat. The macrofauna, also known as the ecosystem engineer (Group A) comprises $11.60 \%$ in CEFS and $3.39 \%$ in Ladang 2. They consist mainly of earthworms, ants, and termites. The second functional group was known as Litters transformer groups (Group B) which made up $15.15 \%$ in CEFS and 7.37\% in Ladang 2. The Litter transformer consisted of Mesofauna (small Annelida and Myriapoda, Acarina and Collembola) and some smaller Macrofauna. The final functional group, also known as the Predatory group (Group C) made up $12.11 \%$ in CEFS and $7.49 \%$ in Ladang 2, including one microfauna-like Nematoda with some Mesofauna-like Acarina and many Macrofauna such as Myriapoda, Hymenoptera, and Araneae.

\section{Discussion}

Choosing two contrasting sampling areas provided the opportunity to test hypotheses regarding the impact of land activities on invertebrate communities. The findings of this study provide ample evidence about the ecological significance of decomposer assemblages in uncultivated as well as cultivated areas. The interaction of invertebrates and soil is the key to the functioning of the ecosystem. Although soils serve as suitable habitats for invertebrates, some of these organisms also cause changes in soil texture and structure by integrating soil organic matter (Zech, 1993; Pappoe et al., 2009). Arthropoda formed the largest phylum (Tables 2,3) indicating it is the most successful and forming the largest group of invertebrates [Postlethwait et al., 1991). However, when the soil environment is disturbed, Mesofaunal (such as Acari, some smaller insect groups, and smaller Araneda) become more and more dominant. The Acari (mites) are an extremely diverse group of arachnids that can successfully adapt to a wide range of habitats (Blakely et al., 2002; Eisenbeis, 2006), in both habitats. However, findings suggest CEFS habitat is more hospitable to different soil fauna than Ladang 2. It is commonly observed that communities living in undisturbed or moderately disturbed habitats were higher and more diverse than those living in habitat frequently disturbed and causing changes in texture and structure, exposed to fertilizer and different pesticides and herbicides applications (Prashar \& Shah, 2016). It is recommended not to make hasty comparisons about soil communities as other factors beyond the scope of this paper might have some influence on the outcome of species composition and diversity. Turbe et al. (2010) explained that contrary to popular belief, disturbances do not necessarily lead to long-term loss of biodiversity, and in many cases, moderate stress can be a positive force, enabling species to coexist, thereby increasing biodiversity. Perhaps this is what happened to the uncultivated field CEFS. Although there were some disturbances in CEFS, because the soil has some grooves or indentations to slow down surface runoff and soil erosion, the soil was covered with wild grass that provided food and shelter for a variety of soil fauna. That is probably the reason why CEFS has higher fauna species composition and diversity than lading 2 . To show that land use and soil type can influence fauna number and diversity. On the other hand, Ladang 2 is the agriculture experimental plot that has been ploughed and tilled from time to time, received fertilizer, herbicide, and pesticide periodically whereas soil in CEFS is virtually undisturbed, free from agricultural activities such as soil tilling, herbicide, and pesticide. Land disturbance and the use of herbicides and pesticides are the most probable agents affecting diversity (Menta, 2012). This paradox is resolved by the average nuisance hypothesis, which posits that biodiversity is highest when the stress is mediocre. The main idea is that, with low disturbance, competitive exclusion arises through dominant species, while with severe disturbance, only stress-tolerant species can survive. Also, in the cultivated field Ladang 2 the intensive tillage and agricultural activity in this site led to increased stress on the diversity of invertebrates, so, the diversity was low. The present findings are in contrast to Frainer and Duarte, (2009). There was a 
difference in the Coleoptera between the two communities where the density was high in the disturbed fields compared to the undisturbed fields, where some coleopterans were resistant to the disturbance (Ronqui \& Lopes 2006; Frainer \& Duarte, 2009). Furthermore, there could be several explanations for differences like the physical properties of the soil, soil cover, soil moisture, soil organic matter that can be the determining factors. It has been argued that communities that are subjected to little disturbance or no nuisance in species compared to those experiencing severe conditions are often produced by pesticide and fertilizer applications and changes in structure and texture (Smith et al., 2008; Abdu et al., 2008; Poppoe et al., 2009). Macrofauna was the highest group in soil invertebrates in both sites. furthermore, this high rate was related to Hymenoptera, which have more influencing the composition of the faunal communities and they have high dispersal ability in different environments (Mateos et al., 2011; Manhães et al.,2013)

\section{Conclusion}

The findings of this study suggest that cultivated fields are generally lower in the number of soil organisms and diversity compared to uncultivated land. Since there are not many similar studies available in the literature, the present study provides valuable baseline data on the diversity of soil surface invertebrates in Universiti Putra Malaysia specifically at the Centre of Environmental Forensic Studies and the Research Farm (Ladang 2). Knowing the species composition and diversity of soil fauna is the first step towards understanding the state of the soil and its contribution to soil health and crop production.

\section{Acknowledgments}

This research was funded by the Putra grant code project: GP/2017/9568000 of UPM Malaysia.

\section{References}

Abdul, G., Muhammad, H., \& Alvi, Z. H. (2008). Biodiversity of earthworm species from various habitats of District Narowal, Pakistan. International Journal of Agriculture and Biology, 10(6): 681-684.

Azevedo, V.F, Pereira, M.G, Corrêa Neto, T.A, Schermack, V, \& Machado, D.L.(2008). Changes in the of the edaphic fauna community due to the burning in secondary forest in Flona Mário Xavier, Seropédica, RJ. R. Ci. Vida, 28: 09-17.
Baretta D, Duarte C.R, Baretta M, \& Cardoso N.E.J.B. (2008). Multivariate attributes analysis in a high Andean forest. Rev. Biol. Trop, 58:1031-1048.

Blakely JK, Neher DA, Spongberg AL. (2002). Soil invertebrate and microbial communities, and decomposition as indicators of polycyclic aromatic hydrocarbon contamination. Applied Soil Ecology, ,21(1):71-88.

Çakır, M., \& Makineci, E. (2018). Community structure and seasonal variations of soil microarthropods during environmental changes. Applied Soil Ecology, 123: 313-317.

Correia, M.E, \& Oliveira, L.C.M. (2000). Soil Fauna: Aspects general and methodological. Seropédica, Embrapa Agrobiology, ;112:46.

Correia, M.E.F. (2002). Relations between the diversity of wildlife and the process of decomposition and its reflections on the stability of ecosystems. Seropédica, Embrapa Agrobiology:156,33.

Cunha Neto, F. V. D., Correia, M. E. F., Pereira, G. H. A., Pereira, M. G., \& Leles, P. S. D. S. (2012). Soil fauna as an indicator of soil quality in forest stands, pasture and secondary forest. Revista Brasileira de Ciência do Solo, 36(5): 1407-1417.

Dias, P. F., Souto, S. M., Correia, M. E. F., de Menezes Rodrigues, K., \& Franco, A. A. (2007). Effect of legume trees on soil macrofauna of a brachiaria brizantha cv. marandu pasture. Pesquisa Agropecuária Tropical, 37(1): 38.

Eisenbeis, G. (2006). Biology of soil invertebrates. In Intestinal microorganisms of termites and other invertebrates Springer, Berlin, Heidelberg: 3-53.

Fauziah, C. I., Jamilah, I., \& Syed Omar, S. R. (1997). An evaluation of cation exchange capacity methods for acid tropical soils. Pertanika Journal of tropical agricultural science, 20: 113-120.

Frainer, A., \& Duarte, M. M. (2009). Soil invertebrates in southern Brazilian Araucaria forestgrassland mosaic: differences between disturbed and undisturbed areas. Iheringia. Série Zoologia, 99(3): 307-312.

Greg S. and Alison E. (2016). Invertebrates: search and extraction methods, Inventory and monitoring toolbox: invertebrates DOCCM-255606.

Grossi, J. L., \& Brun, J. J. (1997). Effect of climate and plant succession on lumbricid populations in the French Alps. Soil Biology and Biochemistry, 29(3-4): 329-333.

Haag H.P, Valera F.P, Chiaranda R, Kikuti P, Chávez J.M, Donald E.L.F, et al. (1985). Nutrient cycling in tropical forests. Campinas, Cargill Foundation,: 144.

Havlin, J. L., Beaton, J. D., Tisdale, S. L., \& 
Nelson, W. L. (2005). Soil fertility and fertilizers: An soil properties. Soil and water management introduction to nutrient management (Vol. 515, pp. 97-141). Upper Saddle River, NJ: Pearson Prentice Hall. module, $1(1): 1-2$.

Mcgeoch MA. (1998). The selection, testing, and Hutcheson, J., Walsh, P., \& Given, D. R. (1999). application of terrestrial insects as bioindicators. Potential value of indicator species for conservation and management of New Zealand terrestrial Biological Reviews,73(2):181-201.

communities Wellington: Department of Menta, C. (2012). Soil fauna diversity-function, soil degradation, biological indices, soil restoration. In Conservation: 90 . world. InTech.

Jeffery, S., Gardi, C., Jones, A., Montanarella, L., Moço, $\quad$ M K $\quad$ S. Gama-Rodrigues, E.F. Marmo, L., Miko, L., ... \& Van der Putten, W. H. Gamarodrigues, A.C. \& Correia, M.E.F. (2005). (2010). European atlas of soil biodiversity. Description edaphic fauna in different vegetation Publications Office of the European Union, North Fluminense region. R. Bras. Ci. Solo, 29: 555Commission européenne, Luxembourg. 564.

Kinasih, I., Cahyanto, T., widiana, A., kurnia, D. N. Nielsen UN, King CK. (2015). Abundance and I., julita, U., \& putra, R. E. (2016). Soil invertebrate diversity of soil invertebrates in the Windmill Islands diversity in coffee-pine agroforestry system at region, East Antarctica. Polar Biology,38(9):1391-400. Sumedang, West Java. Biodiversitas Journal of Pappoe AN, Armah FA, Akotoye HK. (2009). Biological Diversity, 17(2).

Diversity of soil surface invertebrates in cultivated Lavelle P. (1996). Diversity of soil fauna and and uncultivated fields in Coastal Savanna zone of ecosystem function. Biology International. 33:3-16. Ghana. Research Journal of Soil Biology,1(2):77-83.

Lavelle, P., Spain, A. V., Blanchart, E., Martin, A., \& Patrick B. (1994). The importance of invertebrate Martin, S. (1992). Impact of soil fauna on the biodiversity: An Otago Conservancy review. properties of soils in the humid tropics. SSSA Special Department of Conservation.

Publication, 29:157-157.

Postlethwait JH, Hopson JL, Veres RC. (1991).

León-Gamboa, A. L., Ramos, C., \& García, M. R. Biology! : Bringing Science to Life. McGraw-Hill (2010). Effect of pine plantations on soil arthropods in Companies.

a high Andean forest. Revista de biologia tropical, Prashar, P., \& Shah, S. (2016). Impact of fertilizers 58(3): 1031-1048. and pesticides on soil microflora in agriculture. In

Loyola, R. D., Brito, S. L., \& Ferreira, R. L. (2006). Sustainable Agriculture Reviews (pp. 331-361). Ecosystem disturbances and diversity increase: Springer, Cham.

implications for invertebrate conservation. In Ribas CR, Schmidt FA, Solar RR, Campos RB, Arthropod Diversity and Conservation Springer, Valentim CL, Schoereder JH. (2012). Ants as Dordrecht. :25-42.

Maftu'ah, E., Alwi, M., \& Willis, M. (2005). Potential of soil macrofauna as bioindicator of peatland quality. Bioscientiae, 2(1), 1-14.

indicators of the success of rehabilitation efforts in deposits of gold mining tailings. Restoration Ecology,

$12-20$

Manhães, C. M. C., Gama-Rodrigues, E. F., Moço, M. K. S., \& Gama-Rodrigues, A. C. (2013). Mesoand macrofauna in the soil and litter of leguminous trees in a degraded pasture in Brazil. Agroforestry systems, 87(5), 993-1004.

Mason, C.F. (1980). Decomposition - Biology topics. Sao Paulo, EPU / University of São Paulo; 18: 63.

Ronqui, D. C., \& Lopes, J. (2006). Composition and diversity of Scarabaeoidea (Coleoptera) attracted by light trap in the rural areas of Northern Paraná. Iheringia. Série Zoologia, 96(1): 103-108.

Sala OE, Chapin FS, Armesto JJ, Berlow E, Bloomfield J, Dirzo R, et al. (2000). Global Mateos, E., Santos, X., \& Pujade-Villar, J. (2011). Santorufo L, Van Gestel CA, Rocco A, Maisto G. Taxonomic and functional responses to fire and post- (2012). Soil invertebrates as bio indicators of urban fire management of a Mediterranean Hymenoptera soil quality. Environmental Pollution, 161:57-63.

community. Environmental Management, 48(5), 1000. Shannon CE, Weaver W. (1949). The mathematical Materna, J. (2004). Does forest type and vegetation theory of information, AT\&T Tech. J,27,359-423. patchiness influence horizontal distribution of soil Silva R.F, Aquino A.M, Mercante F.M. \& Collembola in two neighboring forest sites? Guimarães, M.F. (2006). Macrofauna invertebrate Pedobiologia, 48(4): 339-347.

McCauley A, Jones C, Jacobsen J. (2005). Basic the Region of the Cerrado. Pesq. Agropec. Bras, 41: 
697-704.

Simpson E.H (1949). Measurement of diversity. Nature, 163, 688, doi:10.1038/163688a0.

Smith RG, McSwiney CP, Grandy AS, Suwanwaree P, Zech, W.( 1993). Geology and Soils. In: Tropical Snider RM, Robertson GP. (2008). Diversity and Forestry Handbook, Pancel, L. (Ed.) Springer-Verlag, abundance of earthworms across an agricultural land- New York:515-567.References in the text should be use intensity gradient. Soil and Tillage Research,100(1-2):83-8. Southwood T.R.E. (1994). Ecological methods. multiple-authored papers.

Chapman \& Hall.. ISBN 0-412-30710-3.

Thyssen P. J. (2010). Keys for Identification of Immature Insects. Current Concepts in Forensic Entomology. :25-42.

Turbe A, Toni A. D, Benito P., Lavelle P., Lavelle P., Camacho N. R. et al. (2010). Soil biodiversity: functions, threats, and tools for policymakers Rapport de synth'ese. <bioemco-00560420> HAL. http://halbioemco.ccsd.cnrs.fr/bioemco-00560420.

Vitousek PM, Mooney HA, Lubchenco J, Melillo JM. (1997). Human domination of Earth's ecosystems. Science, 277(5325):494-9.

Wade KR, Ormerod SJ, Gee AS. (1989). assemblages to predict stream acidity in upland Wales. Hydrobiologia, 171(1):59-78.

inserted in parentheses in full for single and dual authored papers but using the first author and et al. for
Classification and ordination of macroinvertebrate

Figure1: Divided soil invertebrates according to body size and functional group.

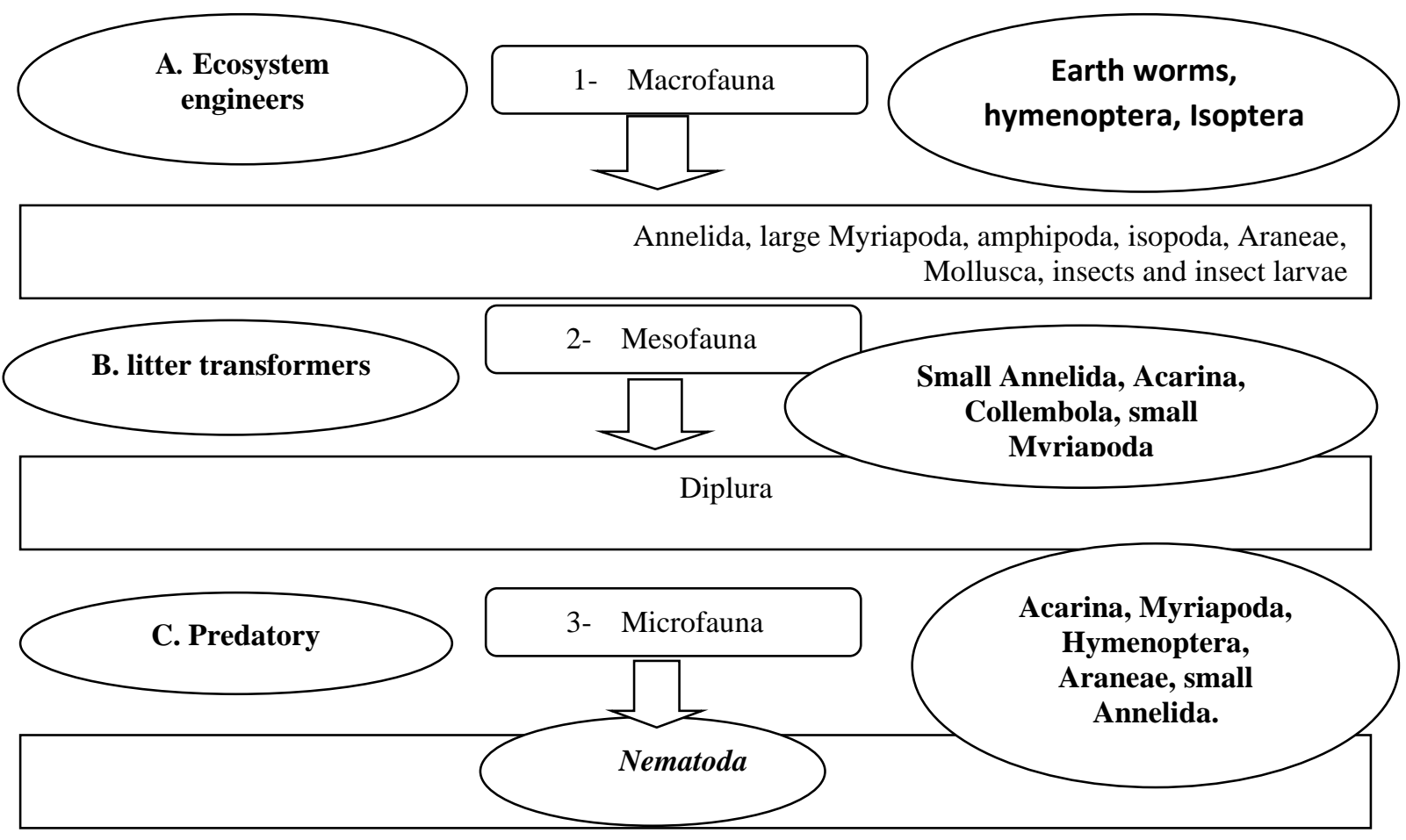

Body size group, $1,2,3$ functional group $\mathbf{A B C}$ 
Figure 2: The deferent percentage between invertebrates groups among 2 sites

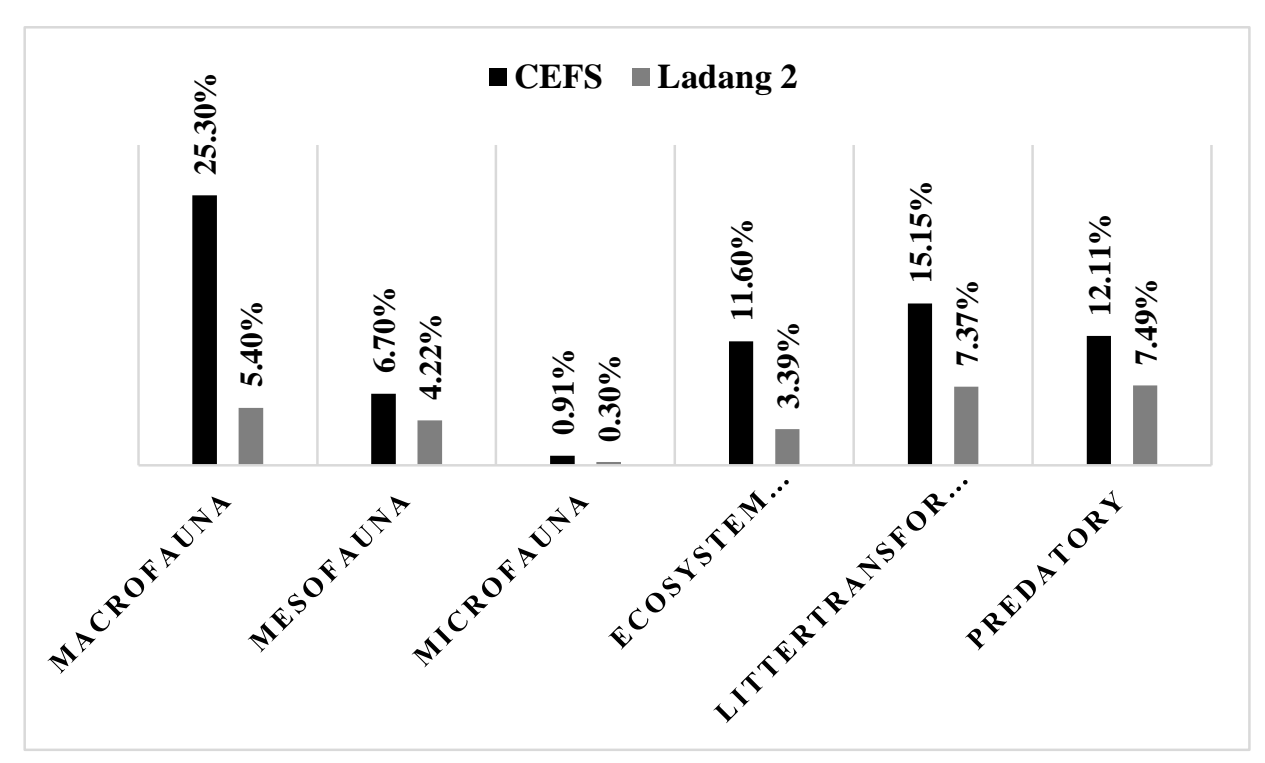

